\title{
Continuous cultivation of Dunaliella salina in photobioreactor for the production of $\beta$-carotene
}

\author{
Yue-Hui Zhu $\cdot$ Jian-Guo Jiang
}

Received: 20 August 2007 / Revised: 18 October 2007 / Accepted: 5 November 2007 / Published online: 24 November 2007

(C) The Author(s) 2007

\begin{abstract}
A helix tube photobioreactor with a volume of $10 \mathrm{~L}$ was designed and manufactured. The facade of the reactor was designed as three-layer frame. The illumination helixes units were 16, illumination area volume was $1.5 \mathrm{~L}$, illuminate specific area was $95 \mathrm{~m}^{-1}$. A marine micro-alga Dunaliella salina was used as a model organism in this study. Results showed that the optimum inoculum concentration was $\mathrm{OD}_{630}=0.15$ and the optimum circulation rate of culture fluid was $630 \mathrm{~mL} / \mathrm{h}$ for the bioreactor. In continuous cultivation, in order to determine the optimum collection of alga solution for the highest yield of $\beta$-carotene, three different alga solution collection and addition fresh culture medium volumes were applied: $0.8,1.5,2.0 \mathrm{~L} /$ day. The biomass and extraction of $\beta$-carotene were determined in different cultivation periods. The result suggested that the optimum daily harvest of alga solution was $1.5 \mathrm{~L} /$ day for the cultivation of $D$. salina to obtain the highest production of $\beta$-carotene.
\end{abstract}

Keywords Dunaliella salina Photobioreactor . Continuous cultivation $\cdot \beta$-carotene

\section{Introduction}

Photobioreactors were used for culturing photosynthetic microorganisms such as microalgae, cyanobacteria, plant cells, and photosynthetic bacteria, for various bio-

\footnotetext{
Y.-H. Zhu $\cdot$ J.-G. Jiang $(\square)$

Food College,

South China University of Technology,

Guangzhou 510640, China

e-mail: jgjiang@ @scut.edu.cn
}

technological applications. There also exist several microalgal-based processes for producing nutraceutical-type products, such as polyunsaturated fatty acids (e.g. eicosapentaenoic acid and docosahexaenoic acid) and carotenoids (e.g. $\beta$-carotene). In addition, bioreactorbased photosynthetic microalgal cultures were being considered as a part of the Closed Ecological Life Support System [1].

$\beta$-carotene is a lipophilic high-value compound and known as pro-vitamin A. $\beta$-carotene is also applied in the food, cosmetic, and pharmaceutical industries as a colorant, antioxidant, and anti-cancer agent [2]. Dunaliella salina is the main source for natural $\beta$-carotene. The green microalga can produce and accumulate $\beta$-carotene under stress conditions such as high light intensity, high salinity, and nutrient deficiency up to a concentration of $10 \%$ of its dry weight [3].

Up to date, the mainly used methods to Cultivate $D$. salina to produce $\beta$-carotene in open-air pond or natural waters were rather extensive [4-6]. The disadvantages of this method include: long light-path, severe dodging actions among algae cells, excess dependence upon the local weather, low utilization ratio of atmospheric $\mathrm{CO}_{2}$ and easy contamination. It is necessary and urgent to develop closed bioreactor and now there were various bioreactors with different form and specifications $[1,7,8]$. However, few of them were of high commercial value, which requires largescale cultivation, due to the technique used or high manufacturing cost.

The present study designs a helix tube photo bioreactor (PBR) with the volume of $10 \mathrm{~L}$, which was based on those bioreactors of the universal principles, and was intended to overcome the above cited problems outdoor cultivation come up against. 


\section{Materials and methods}

Organism and medium

Dunaliella salina $(1 / 2 \mathrm{SW})$ was grown in a culture medium according to Hejazi and Wijffels [9] and Hejazi et al [8] with mirror modification containing $1.5 \mathrm{M} \mathrm{NaCl}, 5 \mathrm{mM}$ $\mathrm{KNO}_{3}, 0.1 \mathrm{mM} \mathrm{NaH} \mathrm{PO}_{4} \cdot 2 \mathrm{H}_{2} \mathrm{O}, 5 \mathrm{mM} \mathrm{MgSO}{ }_{4} \cdot 7 \mathrm{H}_{2} \mathrm{O}$,

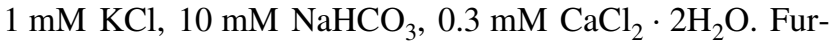
ther, $1 \mathrm{~mL} / \mathrm{L}$ of trace elements stock with $16.2 \mathrm{mM} \mathrm{H}_{3} \mathrm{BO}_{3}$, $9.1 \mathrm{mM} \mathrm{MnCl} 2 \cdot 4 \mathrm{H}_{2} \mathrm{O}, 0.77 \mathrm{mM} \mathrm{ZnSO}{ }_{4} \cdot 7 \mathrm{H}_{2} \mathrm{O}, 0.32 \mathrm{mM}$ $\mathrm{CuSO}_{4} \cdot 5 \mathrm{H}_{2} \mathrm{O}, \quad 0.1 \mathrm{mM} \quad \mathrm{Na}_{2} \mathrm{MoO}_{4}, \quad 9.0 \mathrm{mM}$ $\mathrm{MnSO}_{4} \cdot 7 \mathrm{H}_{2} \mathrm{O}$, and $0.5 \mathrm{~mL} / \mathrm{L}$ of Fe-salting liquid stock with $0.56 \mathrm{mM} \mathrm{Na} 2 \mathrm{EDTA} \cdot \mathrm{H}_{2} \mathrm{O}, 0.77 \mathrm{mM} \mathrm{FeCl}_{3} \cdot 6 \mathrm{H}_{2} \mathrm{O}$. The $\mathrm{pH}$ of the medium after addition of $100 \mathrm{mM}$ of Trisbuffer was adjusted to 7.5 with $2 \mathrm{M} \mathrm{HCl}$. The medium was sterilized at $121^{\circ} \mathrm{C}$ for $30 \mathrm{~min}$ before inoculation.

\section{Biomass and cell number}

The optical density ( $A$ value) of the culture solutions of different concentrations was determined under wavelength $630 \mathrm{~nm}$. Then after centrifugation at $4,000 \mathrm{rpm}$ for $5 \mathrm{~min}$, the pellets was transferred to balanced filter paper, washing with distilled water twice or third and weighed in vacuo at 50 $60^{\circ} \mathrm{C}$. A relationship curve between $\mathrm{OD}_{630}$ and the biomass $(\mathrm{g} / \mathrm{L})$ of dried algae was obtained. In the following experiments by determining $\mathrm{OD}_{630}$ of algae, the biomass was get with the equation of correlation: $y=0.7449 x+0.0146$, $R^{2}=0.982$. Where, $y$ : biomass of dry weight, $x$ : $\mathrm{OD}_{630}$ value.

The cell number was determined by direct counting under a light microscope with a $0.1 \mathrm{~mm}$ deep counting chamber. The $A$ value of the culture solutions of different concentrations was determined with spectrophotometer, and the cell number was counted with haemacytometer using light microscope. From the relationship curve between $A$ and cell number (as ordinate) regression equation the cell number was obtained by determining $\mathrm{OD}_{630}: y=899.08 x-12.544$, $R^{2}=0.9992$. Where, $y$ : cell number $(\times 104), x: \mathrm{OD}_{630}$ value.

Isolation and determination of $\beta$-carotene

$\beta$-carotene standard solutions of different concentrations with pure acetone as solvent were detected under wavelength $453 \mathrm{~nm}$ where was the characteristic spectrum of $\beta$-carotene. Contents of $\beta$-carotene was determined spectrophotometrically. $2 \mathrm{~mL}$ sample was centrifugated at 4,000 rpm for $5 \mathrm{~min}$, discarding supernate and the precipitate was dissolved with $2 \mathrm{~mL}$ acetone solution, shaking and stewing till separated. The pigment extract was moved to a new tube. Repeating above processes until the extract turned to white, then adding $60 \% \mathrm{KOH}$ of $1 / 10$ volume at $49^{\circ} \mathrm{C}$, transferring the supernate without chlorophyll and lipid to $10 \mathrm{~mL}$ volumetric flask and added acetone to the volume. After determining the $\mathrm{A}_{453}$ value, the concentration $\left(\mathrm{CA}_{453}\right)$ of the $\beta$-carotene solution could be found from the standard curve. The relationship between $y=-0.0037 x^{2}+0.1082 x$

\section{The photobioreactor}

The aim of the current development was to combine the advantages of several types of PBRs [10-13] and to build a helix-tube reactor with the volume of $10 \mathrm{~L}$. The photobioreactor was designed as three-layer structure (Fig. 1). The first layer was illumination area, which was composed of 16 helix tubes and fluorescence lamps. The helix tubes were connected in series by closed rubber tubes. A medium storage tank and a peristaltic pump were placed in the second layer. An infrared lamp used for insulation work was set up in the layer as well. Rubber tubes connect the storage tank, the peristaltic pump and the helix tubes. The lower layer was the place where voltage regulator, temperature control instrument, and electric outlet, etc.

\section{Closed reactor part}

A medium storage tank and 16 helix-tube illumination unit(s) composed the closed reactor part. Experimentally

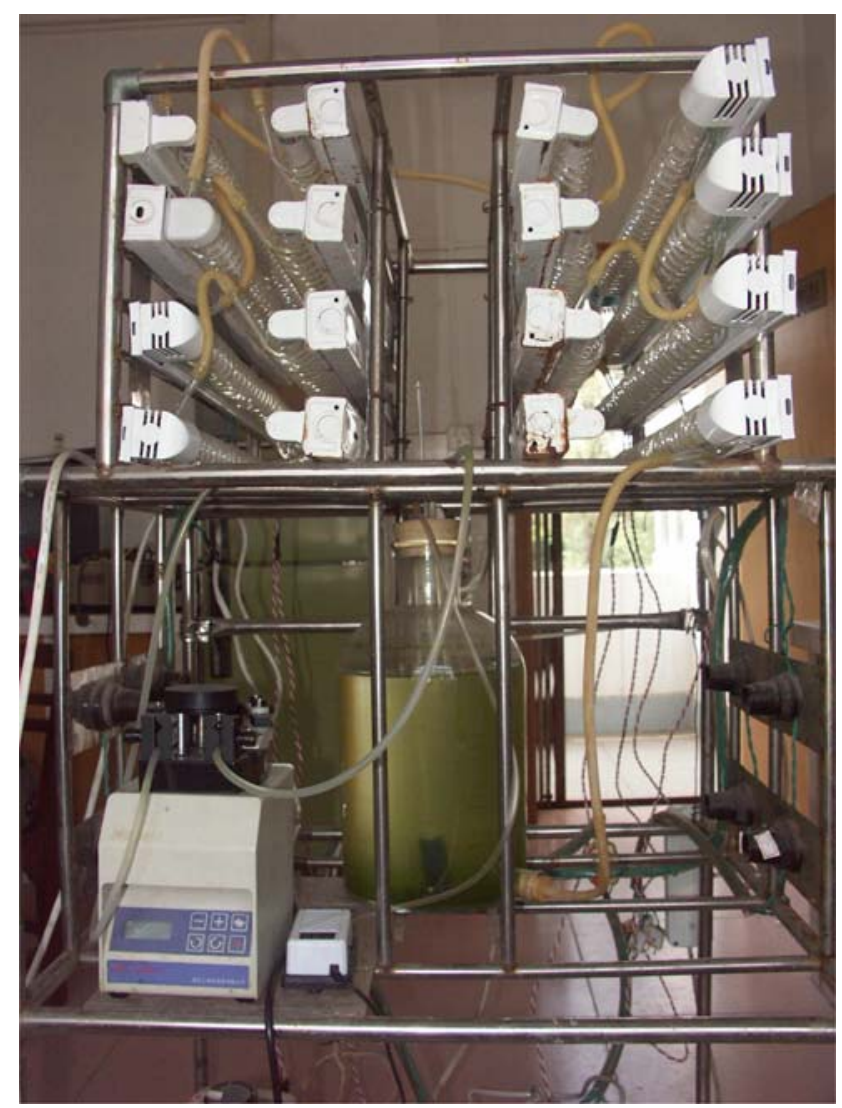

Fig. 1 Structure and flow process chart 
confirmed, common-used pyroceram was superior to organic class as the material making the reaction zone under illumination. The helix-tube design in this PBR was adopted after contrasting different PBR's forms. The inner diameter of the helix can be designed into different sizes, which allow fluorescent tube to across inside the helix. The construction made the fluorescence lamp as inner light source. In a laboratory scale, the daylight lamp was available and economical for PBR. The light intensity of daylight lamp could reach up to 8,000-15,000 lx within $3 \mathrm{~cm}$ from the lamp. So it is adequate to be used as the light source, and when necessary to enforce illumination, PBR could select fluorescent tube with higher power or add illumination unit.

\section{Dynamic system}

This part included peristaltic pump and electric circuit system. The peristaltic pump had two option switches; "fast" and "low", each had nine steps to select, through which the flux of culture medium could be controlled.

\section{Parameter-control systems}

Parameter-control systems consisted of peristaltic, temperature controller, oxygen solution determinator, acidimeter.

\section{Illumination area parameters}

In Fig. 1, illumination zone was made up of one helix tube unit, culture solution flowed out from the entrance of storage tank and was pumped into the helix tube, where culture solution accepted illumination. The air was pumped into the storage tank by gas pump, whose temperature was maintained by infrared lamp. The whole circulating system was in a closed state.

Inner diameter of helix class tube $d=7.5 \mathrm{~mm}$, inner diameter of helix $D=32 \mathrm{~mm}$, thickness of tube wall $1 \mathrm{~mm}$, helix pitch $20 \mathrm{~mm}$, volume of each helix tube was $60 \mathrm{~mm}$, superficial area was $946,521.6 \mathrm{~mm}^{2}$. According to: $S=\mathrm{Sf} /$ $v$, where, $S$ : specific area, $\mathrm{Sf}$ : superficial area, $v$ : volume of total helixes. The total specific area was $95 \mathrm{~m}^{-1}$.

\section{Cultivation process of photobioreactor}

Decanting the inoculated culture solution into storage tank, opening current source, regulating the control instrument to the required temperature. Enabling the peristaltic pump and adjusting the circulating flux of culture solution. According to demands, different inoculum concentrations were determined and added to storage tank. Alga solution from the storage tank was delivered by the pump to the helix tubes illumination area where alga absorb light required for its photosynthesis. After transfluxing all the helix tubes in serials, culture solution flows into storage tank and the circulation accomplishes. During experiment, the temperature of the system was control at $35^{\circ} \mathrm{C}$ by the infrared lamp.

\section{Experiment set-up}

In continuous cultivation, since the reaction volume was in the steady state, the yield of alga culture media was equal to the addition of fresh culture solution. The present research employed a method of gradually increasing flux to determine the optimum flux for the yield of culture solution and addition. The designed experiment continued 24 days after the post-logarithmic phase of cell growth. From the first to 8th day, the yield and the addition of culture solution was $0.8 \mathrm{~L} /$ day, namely $33 \mathrm{~mL} / \mathrm{h}$, the rate of dilution was $0.08 \mathrm{day}^{-1}$. Form the 9 th to 17 th day, the yield and the addition of culture solution increased to $1.5 \mathrm{~L} /$ day, namely $63 \mathrm{~mL} / \mathrm{h}$. The rate of dilution was $0.15 \mathrm{day}^{-1}$, which meant that the specific growth rate of cells from sampling to stable phase was $0.15 \mathrm{day}^{-1}$. Form the 17 th to 25 th day, the yield and the addition of culture solution reached $2.0 \mathrm{~L} /$ day, namely $83 \mathrm{~mL} / \mathrm{h}$. The rate of dilution was $0.2 \mathrm{day}^{-1}$, which meant that the specific growth rate of cells from sampling to stable phase was 0.20 day $^{-1}$.

\section{Result}

Inoculum concentration

In the cultivation of micro-alga, suitable inoculum concentration can effectively shorten the lag phase of cell growth and make it go into logarithmic phase earlier [14]. The shortening of the cultivation cycle has a practical significant for the industrialized aquiculture of micro-alga in photobioreactor. It can improve the productivity and debase cost.

Four inoculum concentrations $\left(\mathrm{OD}_{630}=0.05,0.10,0.15\right.$, 0.20 ) were used in this research. Figure 2 showed that lower inoculum concentrations $\left(\mathrm{OD}_{630}=0.05,0.10\right)$ made the lag phase of cell growth longer than that of higher inoculum concentrations $\left(\mathrm{OD}_{630}=0.15,0.20\right)$, and in the post-logarithmic phase the biomass was lower. At the inoculum concentrations of $\mathrm{OD}_{630}=0.20$, although the cell growth turned into logarithmic phase nearly with no lag phase, its lag phase came earlier. At the inoculum concentrations of $\mathrm{OD}_{630}=0.15$, cell growth rate exceed the other three inoculum concentrations and its biomass in lag phase was highest.

Figure 3 showed that the accumulations of $\beta$-carotene existed some different between different inoculum concentrations, the yield of $\beta$-carotene at higher inoculum concentrations $\left(\mathrm{OD}_{630}=0.15,0.20\right)$ was a litter lager than that of lower $\left(\mathrm{OD}_{630}=0.05,0.10\right)$. But the gap was not much high, 


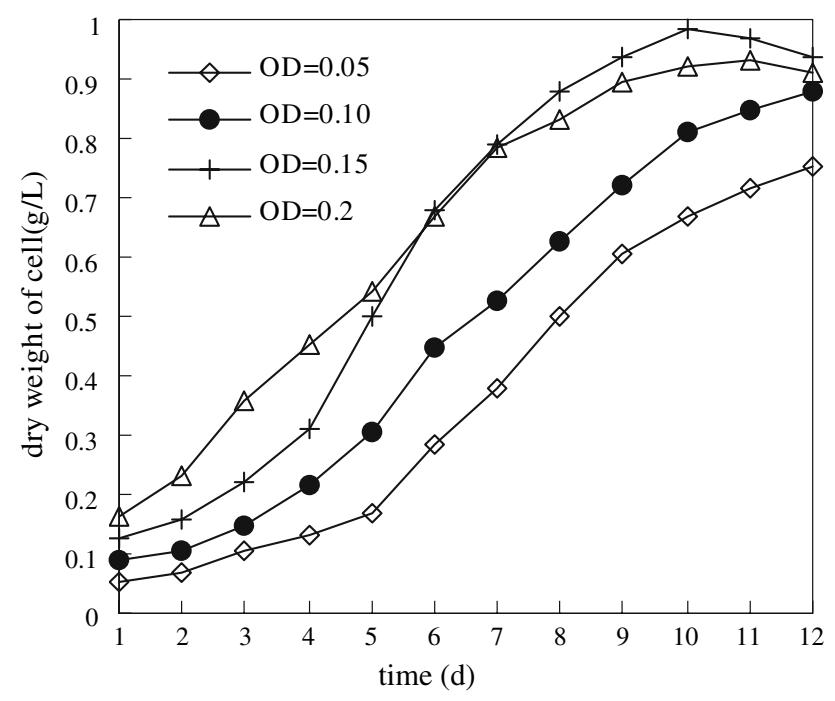

Fig. 2 Growth at different volumes of inoculation

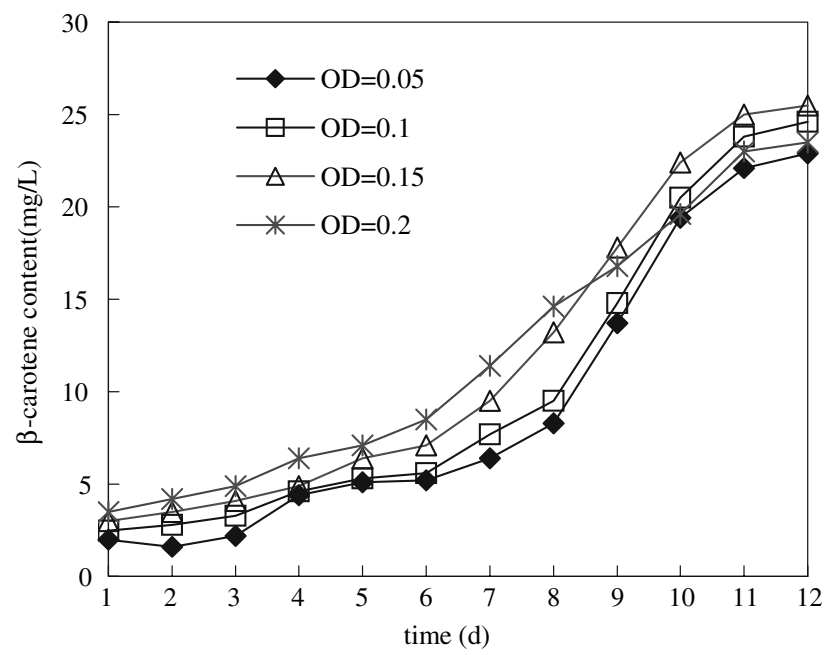

Fig. $3 \beta$-carotene yields at various inoculation concentrations

just within $5 \mathrm{mg} / \mathrm{L}$. At the earlier stage, the increased rate of $\beta$-carotene at the inoculum concentration of $\mathrm{OD}_{630}=0.20$ was faster than that of other three inoculum concentrations, but it was exceeded at the anaphase by lower inoculum concentrations. This indicated that a too higher inoculum concentration was not appropriate to the accumulation of $\beta$ carotene. Possible reason for this was that a higher inoculum concentration make the cells go into balance phase too earlier, which lead to less increase of biomass and yield of $\beta$-carotene. We selected the inoculum concentration of $\mathrm{OD}_{630}=0.15$ for the following experiment.

Circulating flux of culture solution

Circulating flux of alga solution had a larger effect on the growth of D. salina (Fig. 4). When circulating flux was

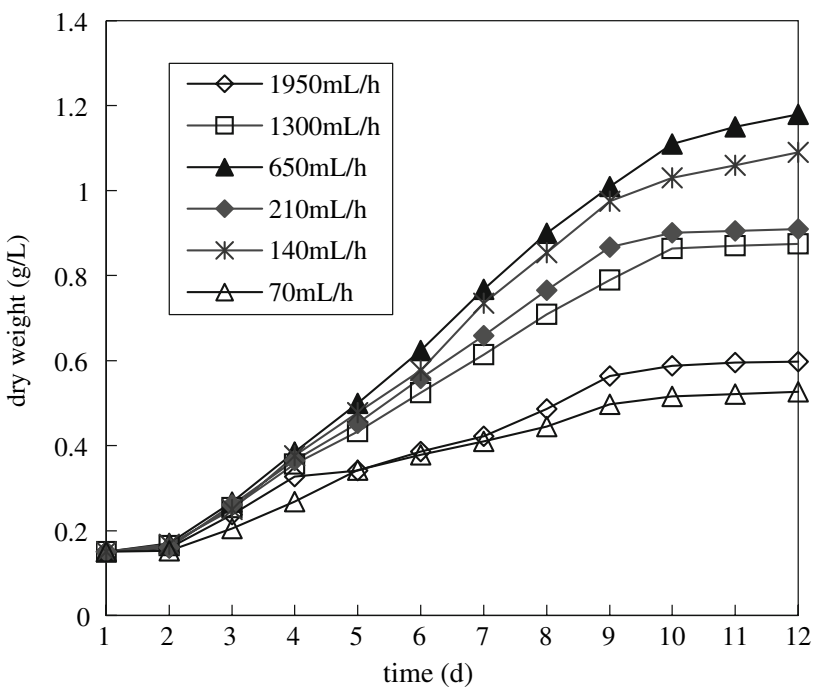

Fig. 4 Relationship between flow rates and biomass

$650 \mathrm{~mL} / \mathrm{h}$, the amplification of biomass was the highest. The dry weight of cell was $1.18 \mathrm{~g} / \mathrm{L}$ after 12-day cultivation. With the same cultivation period, when circulating flux was 1,950 and $1,300 \mathrm{~mL} / \mathrm{h}$, the dry weight of cell was 0.60 and $0.87 \mathrm{~g} / \mathrm{L}$ respectively. While the dry weight of cell was 0.90 , 1.01 and $0.52 \mathrm{~g} / \mathrm{L}$ respectively when the circulating flux was 210,140 and $70 \mathrm{~mL} / \mathrm{h}$. This result suggested when the circulating flux was too high, although the frequency cells accept light increases in one unit of time, the length of cells staying in illuminance area was too short, which did not makes cells absorb enough energy of light. The lower of the circulating flux makes the circulation time longer, which made the total alga solution have not chance to absorb enough energy for photosynthesis, hence effects the biomass accumulation.

The situation that the effect of circulating fluxes of alga solution on the accumulation of $\beta$-carotene was similar (Fig. 5). Too higher or lower circulating fluxes of alga solution both made the content of $\beta$-carotene insufficient. In a suitable flux, the alga solution will accept both a relative higher illumination intensity and higher illumination frequency hence make the yield of $\beta$-carotene highest. Figure 5 showed among the selected circulating fluxes of alga solution, flux $650 \mathrm{~mL} / \mathrm{h}$ was a most suitable flux.

Combining the accumulation of biomass and $\beta$-carotene, $650 \mathrm{~mL} / \mathrm{h}$ was made certain the optimum circulating flux for the following experiment.

Continuous cultivation

Continuous cultivation was a method that makes the cultured microorganism growing in a nearly steady environmental status [15]. During the cultivation period the fresh culture solution was added to the reactor in a stated flux and the old culture solution was collected in the same flux. 


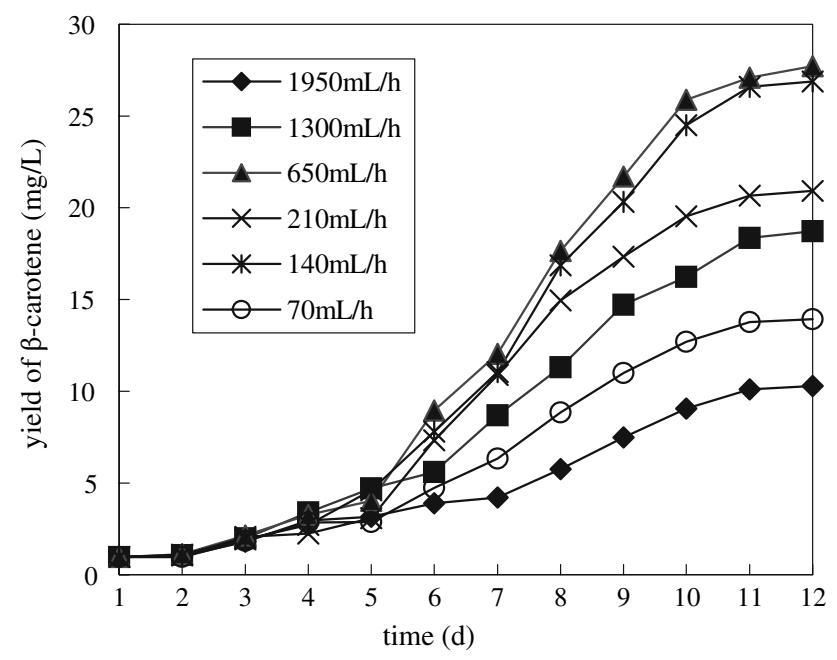

Fig. 5 Relationship between flow rates and $\beta$-carotene

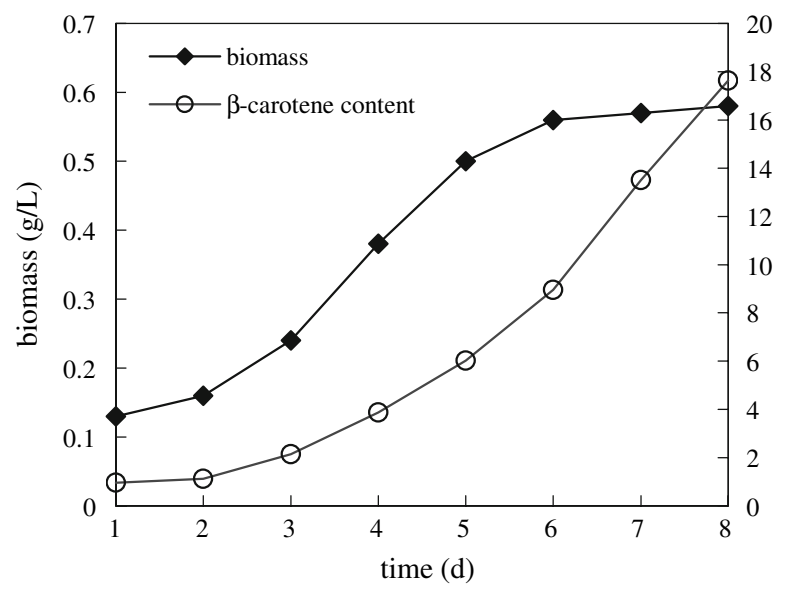

Fig. 6 Curves of continuous culture in photobioreactor (1-8 days)

When the alga solution collection was $0.8 \mathrm{~L} /$ day, the growth of $D$. salina reached balanced state after 6 days (Fig. 6). At that time the biomass was $0.58 \mathrm{~g} / \mathrm{L}$ and content of $\beta$-carotene was $17 \mathrm{mg} / \mathrm{L}$. Modifying the alga solution collection to $1.5 \mathrm{~L} /$ day, we found the biomass increased and reached balanced state at the 14th day. The biomass was $1 \mathrm{~g} / \mathrm{L}$, while the content of $\beta$-carotene continuously went up, and reached $30 \mathrm{mg} / \mathrm{L}$ till the 16th day (Fig. 7). When the alga solution collection was moved up to $2 \mathrm{~L} /$ day, the biomass and content of $\beta$-carotene tended to decrease gradually. When reached the balanced state, the content of $\beta$ carotene decreased to $16 \mathrm{mg} / \mathrm{L}$ and the biomass was just $0.3 \mathrm{~g} / \mathrm{L}$ (Fig. 8).

From the 9th day, the alga solution collection was increased from 0.8 to $1.5 \mathrm{~L} /$ day, and tent to balance. However, the biomass and the $\beta$-carotene content still went up. It was obvious that the collection $0.8 \mathrm{~L} /$ day was a little lower. In a higher collection, the continuous culti-

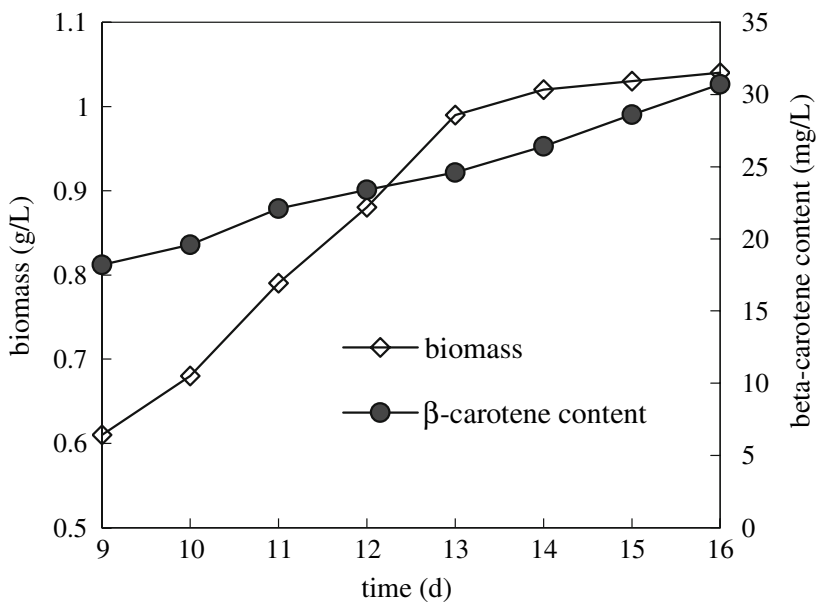

Fig. 7 Curves of continuous culture in photobioreactor (9-16 days)

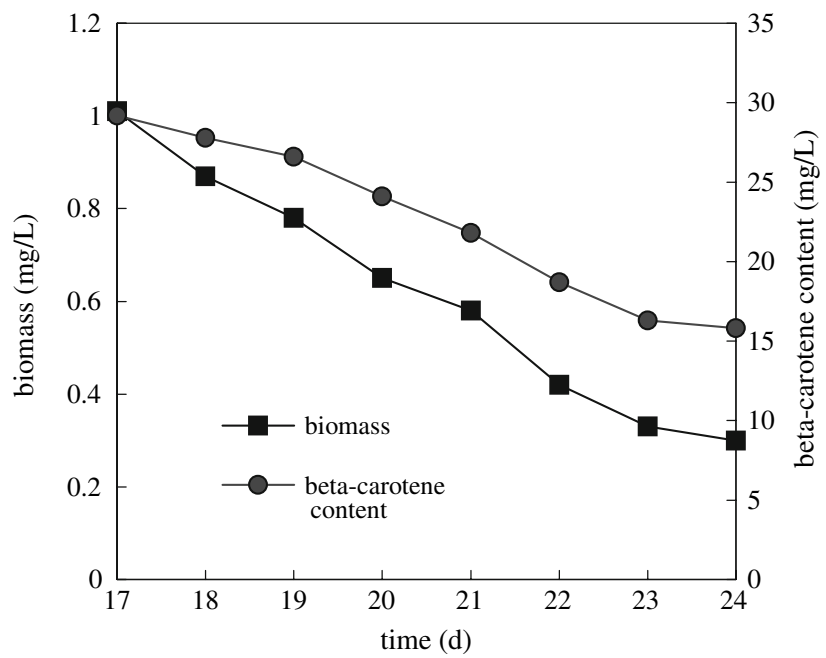

Fig. 8 Curves of continuous culture in photobioreactor (17-24 day)

vation could come to a new balance in a higher biomass and $\beta$-carotene content level. In the collection $1.5 \mathrm{~L} /$ day, the biomass kept in $1 \mathrm{~g} / \mathrm{L}$ of dry weight level, and $\beta$-carotene content reached $30 \mathrm{mg} / \mathrm{L}$. When collection went up to $2 \mathrm{~L} /$ day, biomass and $\beta$-carotene content dropt rapidly, which indicated that $2 \mathrm{~L} /$ day or higher alga solution collection was not suitable for the photobioreactor, addition of $2 \mathrm{~L} /$ day culture solution exceeds the critical dilution value.

The total alga solution volume of the designed photobioreactor was $10 \mathrm{~L}$, in which $1.5 \mathrm{~L}$ alga solution was in the helix illumination area all the time. This $1.5 \mathrm{~L}$ alga solution can absorb enough light for its photosynthesis, the rest $8.5 \mathrm{~L}$ alga solution was in the storage tank and only absorb weak light energy. Therefore, the too higher or too lower of the alga solution collection were both unsuitable. According to the results above, $1.5 \mathrm{~L} /$ day alga solution collections was the optimum. 
The cultured cell density and the aging of culture solution have an effect on the growth of $D$. salina and its accumulation of $\beta$-carotene. Continuous cultivation can solve the problems effectively [16]. Steady state of cultivation environment will be good for the extension of logarithmic growth phase. In the steady status, the environmental condition (e.g. pH, concentration of nutrient substance, product concentration, cell density, etc.) where the microorganism lives in was comparative stable. We can even adjust the growth rate of the cultured alga according to the requirements. Therefore, the major feature of continuous cultivation was that the growth rate of alga cell and its metabolic activity can be controlled for the aim of production [14].

\section{Discussion}

Despite the success of open systems, future advances in microalgal mass culture will require closed systems as the algal species on interest do not grow in highly selective environments. Furthermore, many of the new algae and algal products must be grown free of potential contaminants such as heavy metals and micro-organisms [17]. However their high cost has largely precluded their commercial application until recently.

Open air cultivation of $D$. salina has been successfully mass cultured and marketed commercially. But such approaches do not necessary exclude bacteria and other biological contaminants (e.g. protozoa), thus a major shortcoming of the open culture system. The selection of a particular system is also influenced by intrinsic properties of the alga as well as local climatic conditions and the costs of land and water.

Closed reactors have several advantages such as "clean" algal culture, high light utilization efficiency leading to high productivities as high sustainable biomass, temperature control and the ability to be used outdoors in natural daylight. Continuous culture and good control over the growth environment results in a consistent product quality and the higher operating cell densities also mean that harvesting costs were reduced and there is a smaller requirement for land. The challenge now is to reduce the construction costs of these systems further to make them more economically competitive [18].

Commercial plants based on large-scale closed photobioreactors for Dunaliella $\beta$-carotene production do not seem to operate at present [19]. The arrays of very long and lowdiameter polyethylene tubing, designed in a clearly deficient scaling up of the original pilot-scale device, originated a number of problems that precluded the proper development of the cultures [20].

However, over the last 50 years great advances have been made in our understanding of the biology of the algae and in the engineering requirements of large-scale algae culture systems. This has led to the development of several types of closed photobioreactors which will enable the commercialization of new algae and algal products in the next decade. In recent years there have been several major advances in the design and operation of closed photobioreactors for $D$. salina culture and several systems are likely to be commercial realities in the near future $[1,9]$.

In conclusion, a helpful research was conducted in the present research to make a spiral-tube photobioreactor for the cultivation of $D$. salina in order to increase the output of $\beta$-carotene. The advantages of the reactor in the light utilization ratio is obvious, although some aspects, such as the number of illumination units, more effective light source, the method of continuous cultivation, etc. should be improved further. The application of culturing $D$. salina in the homemade biophotoreactor shows that, the highest biomass and yield of $\beta$-carotene in continuous cultivation are equivalent to that of batch cultivation, about $1 \mathrm{~g} / \mathrm{L}$ and $30 \mathrm{mg} / \mathrm{L}$ respectively. In open pond cultivation, the yield of $\beta$-carotene is generally lower than $20 \mathrm{mg} / \mathrm{L}$. the output of $\beta$-carotene in biophotoreactor is $50 \%$ higher than open pond cultivation, indicating that it is effective to increase the $\beta$-carotene yield by cultivating $D$. salina in the biophotoreactor. If the special conditions in which Dunaliella develops in culture are carefully taken into account, there is still place left for further technological advances and improvements in $\beta$-carotene production by this microalga. This includes enhanced growth performance and higher biomass quality through cultivation in closed photobiorectors.

Acknowledgments The project supported by National Science Foundation of China (20676041) and Guangdong Provincial Science and Technology Foundation of China (2006B36501002).

Open Access This article is distributed under the terms of the Creative Commons Attribution Noncommercial License which permits any noncommercial use, distribution, and reproduction in any medium, provided the original author(s) and source are credited.

\section{References}

1. Li J, Xu NS, Su WW (2003) Online estimation of stirred-tank microalgal photobioreactor cultures based on dissolved oxygen measurement. Biochem Eng J 14:51-65

2. Leach G, Oliveira G, Morais R (1998) Production of a carotenoidrich product by alginate entrapment and fluid-bed drying of Dunaliella salina. J Sci Food Agric 76:298-302

3. Ben-Amotz A (1995) New mode of Dunaliella biotechnology:Twophase growth for h-carotene production. J Appl Phycol 7:65-68

4. Shirai F, Kunii K, Sato C, Teramoto Y, Mizuki E, Murao S, Nakayama S (2003) Cultivation of microalgae in the solution from the desalting process of soy sauce waste treatment and utilization of the algal biomass for ethanol fermentation, World J Microbiol Biotechnol 14(6):839-842

5. Michael AB (1999) Commercial production of microalgae: ponds, tanks, tubes and fermenters. J Biotechnol 70:313-321 
6. García-González M, Moreno J, Cañavate JP, Anguis V, Prieto A, Manzano C, Florencio FJ, Guerrero MG (2003) Conditions for open-air outdoor culture of Dunaliella salina in southern Spain. J Appl Phycol 15(3):177-184

7. Lee YK (2001) Microalgal mass culture systems and methods: Their limitation and potential. J Appl Phycol 13:307-315

8. Hejazi MA, Andrysiewicz J, Wijffels RH (2003) Effect of mixing rate on $\beta$-carotene production and extraction by Dunaliella salina in two-phase bioreactors. Biotechnol Bioeng 84:591-596

9. Hejazi MA, Wijffels RH (2003) Effect of light intensity on $\beta$-carotene production and extraction by Dunaliella salina in two-phase bioreactors. Biomol Eng 20:171-175

10. Ogbonna JC, Yada H, Tanaka H (1995) Light supply coefficient: a new engineering parameter for photobioreactor design. J Ferment Bioeng 80:369-376

11. Pulz O, Scheibenbogen K (1998) Photo bioreactors: design and performance with respect to light energy input. In: Scheper T (ed) Advances in biochemical engineering: biotechnology, vol 59. Springer, Berlin, pp 124-152

12. Meireles LA, Azevedo JL, Cunha JP, Malcata FX (2002) On-line determination of biomass in a microalga bioreactor using a novel computerized flow injection analysis system. Biotechnol Prog 18:1387-1391

13. Katsuda T, Arimoto T, Igarashi K, Azuma M, Kato J, Takakuwa S, Ooshima $H$ (2000) Light intensity distribution in the externally illuminated cylindrical photo-bioreactor and its application to hydrogen production by Rhodobacter capsulatus. Biochem Eng J 5(2):157-164

14. Baquerisse D, Nouals S, Isambert A, dos Santos PF, Durand G (1999) Modeling of a continuous pilot photobioreactor for microalgae production. J Biotechnol 70:335-342

15. Meijer JJ, ten Hoopen HJ G, van Gameren YM, Luyben KChAM, Libbenga KR (1994) Effects of hydrodynamic stress on the growth of plant cells in batch and continuous culture. Enzyme Microb Technol 16:467-477

16. Acien Fernandez FG, Garcia Camacho F, Sanchez Perez JA, Fernandez Sevilla JM, Molina Grima E (1998) Modeling of biomass productivity in tubular photobioreactors for microalgal cultures: effects of dilution rate, tube diameter, and solar irradiance. Biotechnol Bioeng 58:605-616

17. Borowitzka MA (1999) Commercial production of microalgae: ponds, tanks, tubes and fermenters. J Biotechnol 70(1-3):313-321

18. Tsygankov AA (2001) Laboratory scale photobioreactors. Appl Biochem Microbiol 37(4):333-341

19. Del Campo JA, Garcia-Gonzalez M, Guerrero MG (2007) Outdoor cultivation of microalgae for carotenoid production: current state and perspectives. Appl Microbiol Biotechnol 74(6):11631174

20. Tredici M (2004) Mass production of microalgae: photobioreactors. In: Richmond A (ed) Handbook of microalgal culture. Blackwell, Oxford, pp 178-214 